\title{
What is the impact of research with Morus nigra? - A scientometric study
}

\author{
Qual o impacto da pesquisa com Morus nigra? - Um estudo cienciométrico \\ ¿Cuál es el impacto de la investigación con Morus nigra? - Un estudio cientométrico
}

Received: 02/10/2021 | Reviewed: 02/14/2021 | Accept: 02/16/2021 | Published: 02/25/2021

\author{
Meriane Lourdes de Paiva Brandão \\ ORCID: https://orcid.org/0000-0003-3308-8208 \\ Universidade Federal de Goiás, Brazil \\ E-mail: merianebbrandao@gmail.com \\ Camila Aline Romano \\ ORCID: https://orcid.org/0000-0002-3564-6368 \\ Universidade Federal de Goiás, Brazil \\ E-mail: camilaalineromano@gmail.com \\ Andressa Tuane Santana Paz \\ ORCID: https://orcid.org/0000-0002-2754-7474 \\ Universidade Federal de Goiás, Brazil \\ E-mail: andressa.santanapaz@gmail.com \\ José Realino de Paula \\ ORCID: https://orcid.org/0000-0002-4424-7692 \\ Universidade Federal de Goiás, Brazil \\ E-mail: jose_realino@ufg.br
}

\begin{abstract}
Mulberry (Morus spp.) is an evergreen tree belonging to the Moraceae family. The genus Morus has numerous described species, including Morus nigra, an important plant in agriculture and traditional cultures. The objective of this study was to conduct a scientometric research on the species M. nigra. Bibliographic data was been obtained from the Web of Science database considering two times periods. These analyzes showed that research involving $M$. nigra is concentrated in the areas of nutrition, pharmacology and agronomy science. Eastern countries and Brazil are the largest producers of knowledge about $M$. nigra. The research has shown different interests in recent decades, showing that the scientific knowledge produced about the species is associated with the objective for which the plant was used throughout history. There is a trend in the growth of publications focused on the potential antioxidant of $M$. nigra products. The articles had a greater impact factor in the past, however, a significant growth trend in research with $M$. nigra in the last three years, also suggested by the increase in the number of publications in the period. Understanding the publication standards assist in directing future research as well as in understanding the current panorama of research associated with the species.
\end{abstract}

Keywords: Black mulberry; Morus genus; Trends in research.

\section{Resumo}

A amoreira (Morus spp.) é uma árvore perene que pertence à família Moraceae. O gênero Morus possui inúmeras espécies descritas, incluindo Morus nigra, uma planta importante na agricultura e nas culturas tradicionais. O objetivo deste estudo foi realizar uma investigação cienciométrica sobre a espécie $M$. nigra. Os dados bibliográficos foram obtidos na base de dados Web of Science considerando dois períodos de tempo. Essas análises mostraram que as pesquisas envolvendo $M$. nigra estão concentradas nas áreas de nutrição, farmacologia e ciências agronômicas. Os países do Leste e o Brasil são os maiores produtores de conhecimento sobre M. nigra. As pesquisas mostraram diferentes interesses nas últimas décadas, mostrando que o conhecimento científico produzido sobre a espécie está associado ao propósito para o qual a planta foi utilizada ao longo da história. Há uma tendência crescente de publicações com foco no potencial antioxidante dos produtos de M. nigra. Os artigos tiveram um fator de impacto maior no passado, porém, uma tendência de crescimento significativo das pesquisas com M. nigra nos últimos três anos, sugerida também pelo aumento do número de publicações no período. Compreender os padrões de publicação ajuda a orientar pesquisas futuras, bem como compreender o panorama atual de pesquisas associadas às espécies.

Palavras-chave: Amora preta; Gênero morus; Tendências em pesquisa.

\section{Resumen}

La morera (Morus spp.) Es un árbol de hoja perenne que pertenece a la familia Moraceae. El género Morus tiene numerosas especies descritas, incluida Morus nigra, una planta importante en la agricultura y las culturas tradicionales. El objetivo de este estudio fue realizar una investigación cienciométrica sobre la especie $M$. nigra. Los datos bibliográficos se obtuvieron de la base de datos Web of Science considerando dos períodos de tiempo. Estos análisis mostraron que la investigación que involucra a $M$. nigra se concentra en las áreas de nutrición, farmacología y 
ciencias agronómicas. Los países del este y Brasil son los mayores productores de conocimiento sobre $M$. nigra. La investigación ha mostrado diferentes intereses en las últimas décadas, demostrando que el conocimiento científico producido sobre la especie está asociado al objetivo para el que se utilizó la planta a lo largo de la historia. Existe una tendencia en el crecimiento de publicaciones centradas en el potencial antioxidante de los productos de $M$. nigra. Los artículos tuvieron un mayor factor de impacto en el pasado, sin embargo, una tendencia de crecimiento significativo en la investigación con $M$. nigra en los últimos tres años, también sugerida por el aumento en el número de publicaciones en el período. La comprensión de los estándares de publicación ayuda a orientar la investigación futura, así como a comprender el panorama actual de la investigación asociada a la especie.

Palabras clave: Morera negra; Género morus; Tendencias en la investigación.

\section{Introduction}

The genus Morus consists of approximately 24 species, a subspecies, with at least 100 varieties being described (Tutin et al., 1996). The taxonomy of this genus is complex, with more than 150 of the described species, but only 10 to 16 are generally accepted. Classification becomes even more difficult due to the frequent hybridization between species and the fact that many of them are fertile. Within the genus Morus, the species Morus nigra L (1753), popularly known as, blackberry, originates in Iran and disperses to different parts of the world (Ercisli \& Orhan, 2007). In Brazil, its probable introduction occurred in the colonial period (Almeida, 2002; Kumar\& Chauhan, 2008). However, its large-scale cultivation began with Japanese immigration in the 1900s (Padilha et al., 2009).

The development of $M$. nigra is strongly been determined by climatic conditions. Very high temperatures tend to hinder its growth. The cultivation of blackberry was introduced in 1970 by the Experimental Station of Pelotas, now Embrapa Clima Temperado. Since then, the cultivation areas have been expanding from Rio Grande do Sul to São Paulo and Minas Gerais (Antunes, 2002). In terms of world production, there are 20,035 hectares cultivated with an increase of $45 \%$ of the planted area in the last 12 years. In South America the values are approximately 1,597 ha. In Brazil, approximately 250ha with a production of 780 tons, of which about $15 \%$ are, exported (Clarck, 2006). M. nigra is widely used in food and also pharmacology, with different proven biological activities (Padilha, 2009).

Scientific interest in M. nigra in Brazil began in 1972 with the genetic improvement program proposed by Embrapa through the planting of seeds produced by more than fifty crossings carried out at the University of Arkansas, producing more than 12,000 seedlings, originating the first cultivars (Bassols \& Moore, 1981). As a pioneer in the production of blackberry, the state of Rio Grande do Sul is the largest producer, reaching around 700 tons/year. The state is considered the main Brazilian producer, where the Tupy variety is grown, which corresponds to $70 \%$ of the cultivated area (Lorenzi, Bacher \& Lacerda, 2006). The cultivation of mulberry consists of a rustic plantation, with easy management and that does not require large extensions of planted area and therefore promising for family farming (Antunes, 2002).

Considering that the spatial distribution of M. nigra in Brazil is historically linked to the development of research, at first linked to agronomic science, in addition to the nutritional and pharmacological potential of the species, the objective of this work was to investigate the reasons that guide research on M. nigra, globally in the last decade, evaluating factors that can show which trends in research with $M$. nigra from the quantitative analysis model or scientometric study.

\section{Methodology}

In order to know the historical scenario and the perspectives in research with M. nigra, a bibliographic survey was carried out, with a scientometric character, where mathematical tools are used to help formulate hypotheses and predict phenomena involving the topic of interest. (Pereira et al., 2018). The bibliographic survey used in the study was carried out on the Web of Science database using the descriptors "Morus nigra NOT Black mulberry" and "Black mulberry NOT Morus nigra" present in the title field. Only productions in the "original article" or "review" format were been used. Two searches 
were been carried out, without time restriction and another with a filter in the period from 2009 to 2019 . The diversity of journals obtained in the search was been evaluated using the Shannon-Wiener ecological index (H ') (Carvalho, Diniz-Filho \& Bini, 2005; Carneiro, Nabout \& Bini, 2008) commonly used in scientometric studies. To assess the time trend in studies with M. nigra, we chose to analyze the Principal Component Analysis (PCA) based on the grouping of keywords by year of publication (Carneiro et al., 2008; Nabout et al., 2012). The data were been submitted to statistical analysis with the aid of the PAST 4.01 software (Hammer, Harper \& Ryan, 2001).

\section{Results and Discussion}

The research resulted in 184 publications between original articles and reviews, distributed over four decades of research. Searches without time restriction resulted in 22 articles between 1971 and 1999. During this period, publications were associated with plant science and medicinal chemistry, probably due to the wide use of the species for therapeutic purposes. From the 2000s, publications with M. nigra were more frequent (Figure 1), and in the last decade there was been an increase of more than 50\% in the number of articles published. To know 2017 was the year in which publications reached their highest number.

Figure 1. Articles published with Morus nigra or black mulberry per year (2000-2019).

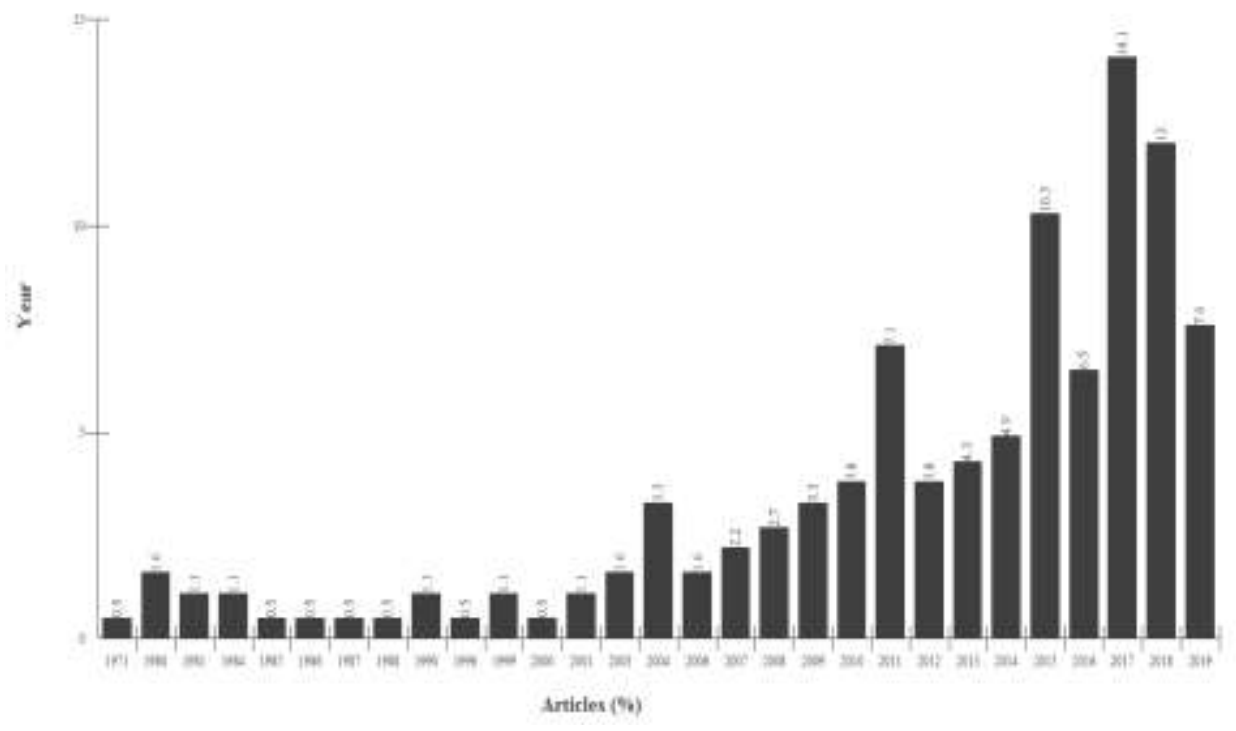

Source: Authors.

The publications with $M$. nigra have come from different countries, the main ones being Turkey, Brazil and China (Figure 2). Most of the countries that have research projects involving M. nigra are concentrated in the Middle East and Asia. This interest is probably been linked to the origin of the species as well as cultural aspects. Mulberry is a plant of Iranian origin, but with worldwide distribution. Its cultivation varies according to the traditional use of the region, for example, in Tunisia M. nigra is only for the production of fruits that can be eaten fresh or processed (Aljane \& Sdiri, 2016). In some countries like China and India, mulberries have been cultivated since the 16th century, especially to obtain leaves that serve as food for the creation of Bombyx mori (Ercisli \& Orhan, 2007). Elsewhere in the world, fruits are been consumed in a variety of ways and leaves are used to make teas and even to feed ruminants in some countries (Ercisli \& Orhan, 2007; Kumar \& Chauhan, 2008). 
Figure 2. Countries that more research Morus nigra plant.

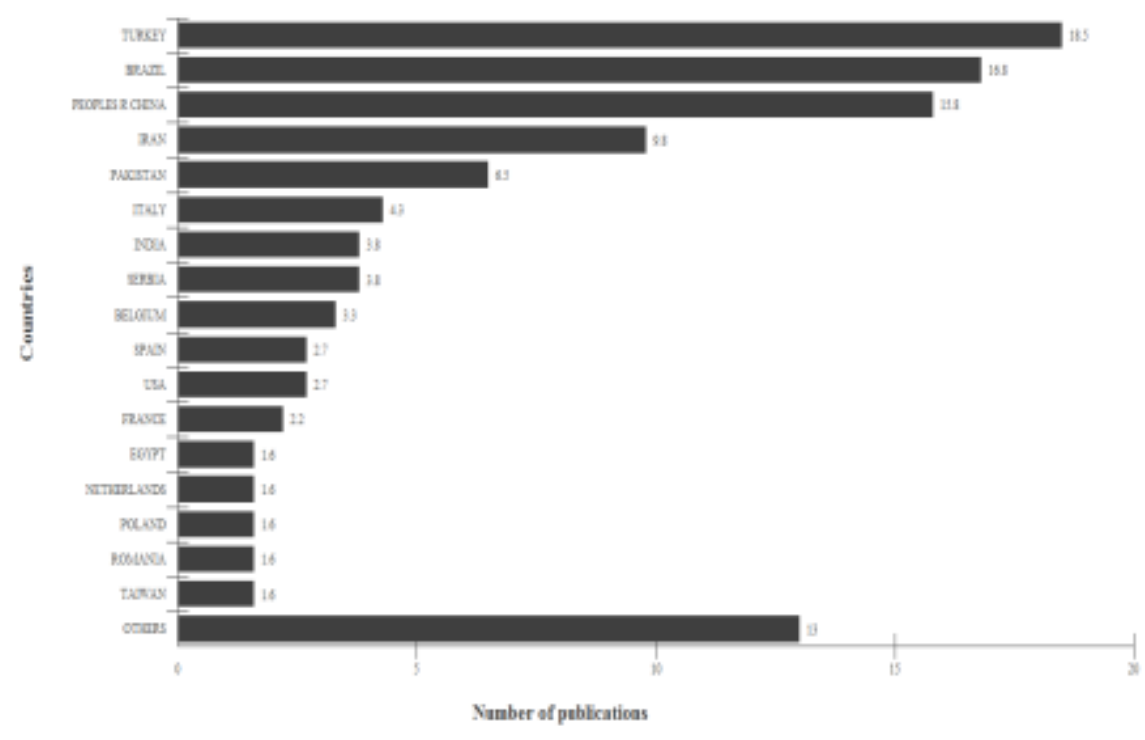

Source Authors.

M. nigra brought to Brazil in the colonial period and has adapted very well to climatic conditions, such as subtropical and tropical climate (mild to hot climate). In Brazil, it seems introduced since the colonial period (Almeida, 2012; Kumar, Chauhan, Bhardwaj, Kumar \& Tyagi, 2011). It is a species that has expanded its cultivated areas in recent years, from Rio Grande do Sul (main Brazilian producer) to other states where the climate is favorable. M. nigra stands out on the national scene for its adaptability to the environment, for its productivity, as well as for its high value as a functional food among others. The Brazilian production of M. nigra went from 250ha to 500ha between the years 2005 and 2014. By 2017, 527.8ha had already planted (Antunes et al., 2014). This cultural and economic panorama justifies the interest of these countries in researching different aspects related to the species.

Publications with M. nigra have concentrated, especially in recent years, on three areas of knowledge: food science, medical chemistry and agriculture science (Figure 3 - a). This trend is evident when looking at the magazines with the largest number of publications with the term "Morus nigra" (Figure 3 - b). The estimated diversity was 4,583, with evenness of 0.975. The results obtained in the evaluation of the areas of interest corroborate the different uses of the species by human populations. 
Figure 3. Area of concentration of research with Morus nigra. In a) concentration area; b) main journals that published articles about the species.

A)

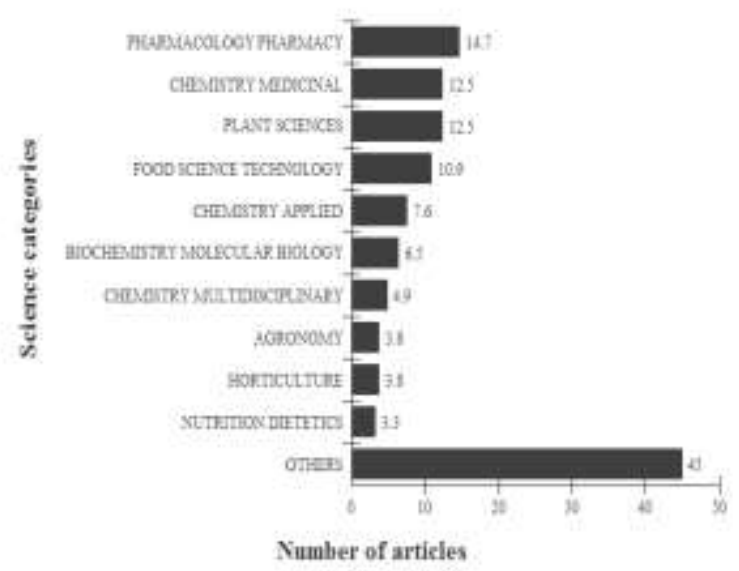

B)

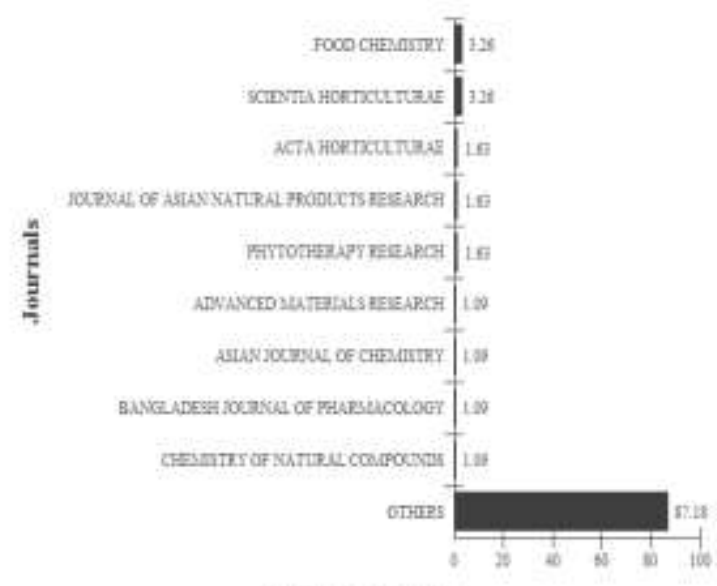

Namber of articles

Source Authors.

M. nigra fruits have a sweet or slightly acidic taste, when ripe they have a black color (Morgan, 1982). They are consumed fresh or processed, such as jams, syrups, drinks, dehydrated, and can also been used in the production of natural dyes (Gundogdu et al.,2011). In addition to food use, the species is also been used for therapeutic purposes. In traditional Chinese medicine, M. nigra leaves are used as an antiphlogistic, hepatoprotective, hypotensive, antipyretic, analgesic, diuretic, expectorant, against diabetes symptoms (Chen et al. 1995), as well as in the treatment of anemia and arthritis (Özgen, Serçe \& Kaya, 2009). The agronomic value of M. nigra is associated with the production of biomass to feed cattle and B. mori herds (Park et al., 2013; Wu et al., 2013).

Publications with M. nigra in the last 20 years had an average impact factor of 1,674. The publications with the greatest impact occurred in the years 2002, 2004 and 2006. Over time, the impact of the publications remained until 2018, when the indicators started to rise again (Figure 4). Citation averages also follow this trend. The appearance of publications with growth in the impact factor shows that the plant has gained visibility in the last three years. The studies appear concentrated in specific and related sectors such as nutritional and pharmacobotanicals aspects. 
Figure 4. Correlation between key words and year of publication. The areas with the strongest hues represent the themes with the greatest repetition.

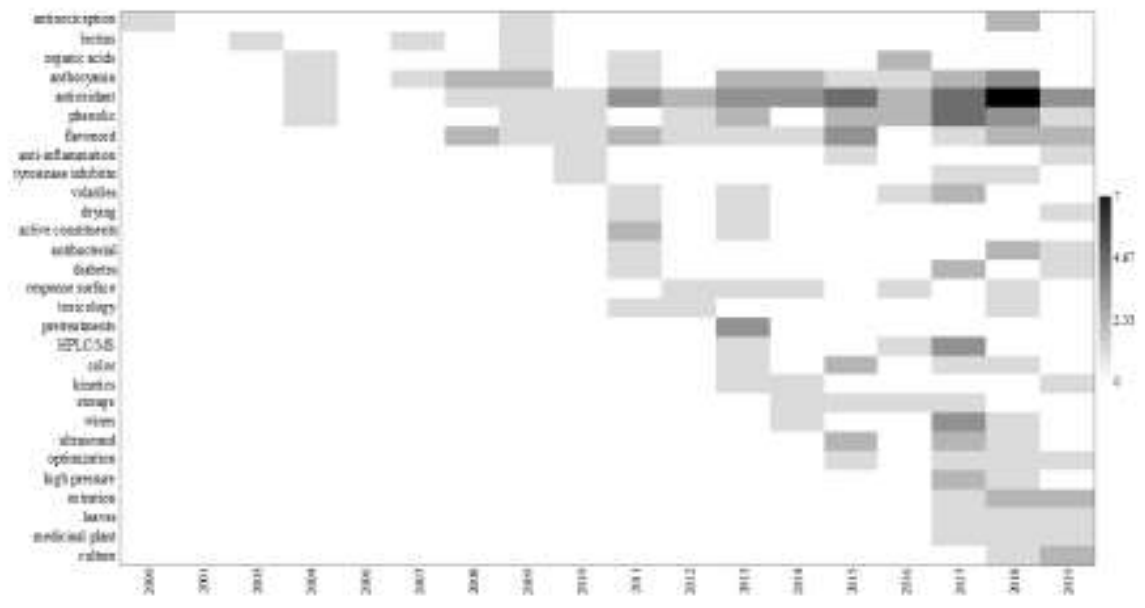

Source Authors.

Considering that the areas of interest are associated with the purpose for which $M$. nigra is cultivated, the main subjects investigated about the species were been investigated. The multivariate analysis correlated the temporal factor with the keywords obtained in the publications. It was possible to perceive a clear temporal organization in the type of research performed (Figure 5). Until 2010, the investigations carried out were restricted to the chemical characterization of the species and the bioactivity of its extracts. Between 2010 and 2015, publications expressed the interest of researchers, especially in extractive processes and toxicological aspects. However, the greatest wealth of studies occurred in the last three years, with a strong emphasis on the anti-oxidant potential of $M$. nigra products.

Figure 5. Impact factor of publications with the term Morus nigra over time and average citations per year.

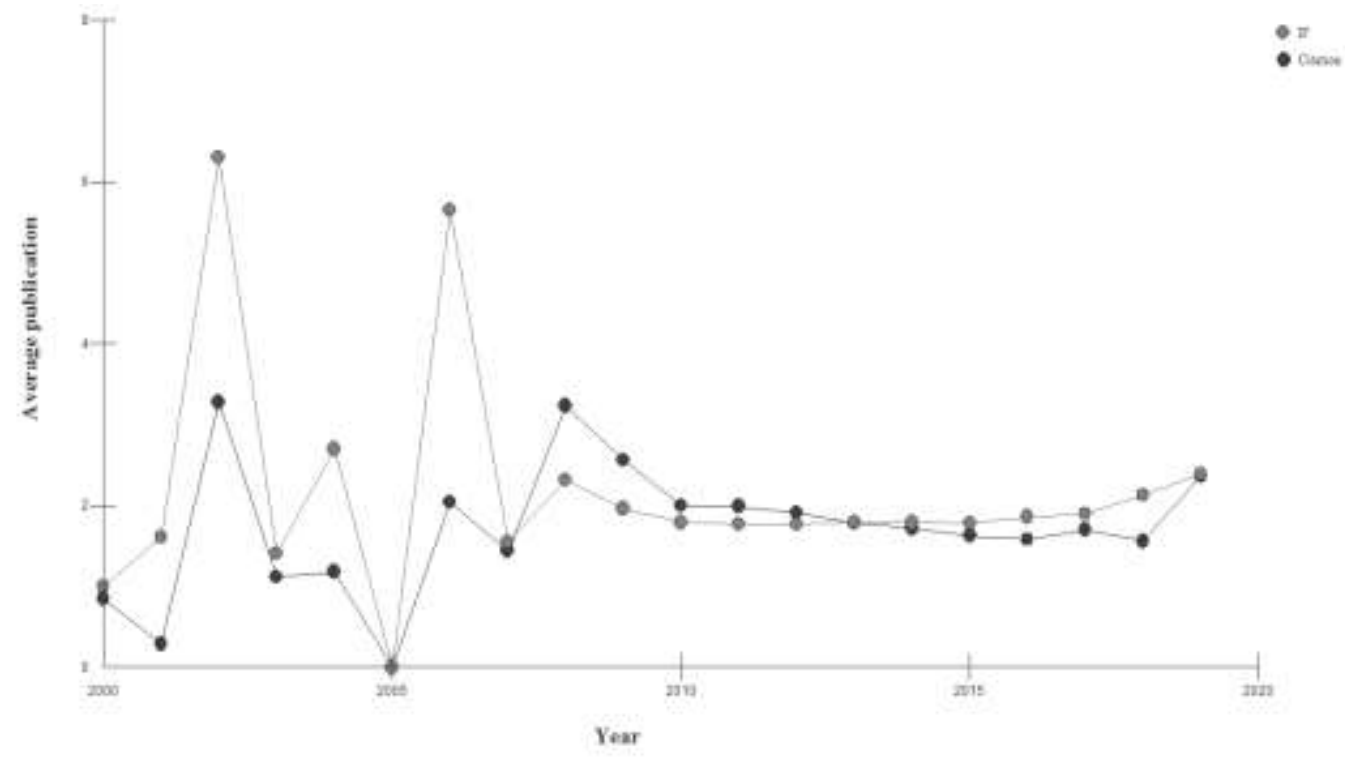

Source Authors.

The concentration of studies involving the elucidation of the chemical composition of $M$. nigra is probably associated with popular practices, where different parts of the plant are been used in preparations to M. nigra for various medicinal 
purposes. Its leaves have widespread use mainly for the treatment of diabetes, cholesterol, cardiovascular problems, obesity and gout (Oliveira et al., 2018). Previous studies have shown that extracts prepared with M. nigra leaves reduce blood glucose and cholesterol levels (Volpato et al., 2011). Its roots and bark may have anti-anemic, anti-inflammatory action when associated with arthritis and rheumatism, in addition to anti-hypertensive (Özgen et al., 2009; Hu et al., 2018). Other research also has been shown anti-aging (Hu et al., 2018;), antibacterial, cytotoxic and antioxidant, antidepressant and neuroprotective, anti-inflammatory and antinocepective (Chen et al., 2016; Cruz-Calsavara et al., 2018 Ribeiro et al., 2019; Lim \& Choi, 2019), neuroprotective effect (Kawvised, Wattanathorn \& Thukham-Mee 2017) and nutraceutical (Miljkovick et al., 2015).

The growing interest in researching M. nigra appears mainly associated with the anti-oxidant potential presented by its extracts, concentrating the studies associated with this potential, suggesting that future research is focused on this activity. High intake of plant products is associated with a reduction in the risk of different chronic diseases associated with oxidative damage. According to Podsedek (2007) this protection is attributed to substances that have antioxidant activity, such as vitamins $\mathrm{C}$ and $\mathrm{E}$, carotenoids, phenolic compounds and especially flavonoids; that interrupt the oxidative process by absorbing free radicals. It is believed that supplementing the diet with herbs, containing high concentrations of compounds capable of deactivating free radicals, also has beneficial effects (Capecka, Mareczek \& Leja, 2005).

Reactive oxygen species and their probable involvement in human pathophysiology have attracted the interest of several sectors of society involved in public health (Laguerre, Lecomte \& Villenueve, 2007). The mechanisms by which these pathologies develop come from oxidative changes in important molecules such as proteins, carbohydrates, nucleic acids, in addition to the substances involved in the modulation of gene expression and inflammatory responses (Kawanish et al., 2002). The actions of antioxidant molecules abundant in the fruits of $M$. nigra can act in the protection of the organism against oxidative damage and consequently in the progress of some chronic diseases. act entirely in neutralizing the action of the reactive classes or with their function to indirectly contribute to enzymatic systems (Oliveira et al., 2018) making it an interesting object in the research and development of drugs and nutraceuticals.

\section{Conclusion}

Research on M. nigra research has shown that the scientific knowledge produced about the species is associated with the purpose for which the plant has been used throughout history. This fact is proven when it was observed that scientific production in the fields of nutrition and pharmacology has an epicenter in eastern countries where its culinary and medicinal use is more widespread in addition to having a historical and cultural character. In Brazil, research in agricultural science is dominant, standing out, following the trend of expanding the cultivation of mulberry in the country.

The articles had a greater impact factor in the past, however, a significant growth trend in research with M. nigra in the last three years, also suggested by the increase in the number of publications in the period. It was noted that the researchers' interest is concentrated on the antioxidant potential presented by the different blackberry preparations. In this sense, the trend is for research with M. nigra to continue expanding, suggesting that scientific production is associated with research, optimization and development of products associated with the species' antioxidant potential. However, more surveys should be carried out to better understand the state of the art of research with M. nigra and its nutritional and pharmaceutical potential.

\section{Acknowledgments}

The authors are grateful for the financial support obtained from Coordenação de Aperfeiçoamento Pessoal de Nível Superior - Brasil (CAPES) - Financer Code 001, CNPq and FAPEG. 


\section{References}

Aljane, F., \&Sdiri, N. (2016). Morphological, phytochemical and antioxidant caharacteristics of white (Morus alba L.), red (Morus rubra L.) and rlack (Morus nigra L.) mulberry fruits grown in arid regions of Tunisia. Journal of new sciences Agriculture and Biotechnology, 35(351), $1940-1947$.

Almeida, J. R. G. S., Souza, G. R., Araujo, E. C. C., Silva, F. S., Lima, J. T., Ribeiro, L. A. A., \& Santos, M. R. V. (2012). Medicinal Plants and Natural Compounds from the Genus Morus (Moraceae) with Hypoglycemic Activity: A Review. In: Sureka Chackrewarthy. (Org.). Glucose Tolerance. (1 ${ }^{\text {st }}$.ed.) Rijeka - Croatia: InTech - Open Access Publisher, 1, 189-206.

Antunes, L. E. C. (2002). A cultura da amora-preta: EPAMIG, 28 p.

Antunes, L. E. C., Pereira, I. dos S., PicolottoI, L., Vignolo, G. K., \& Gonçalves, M. A. (2014). Produção de amoreira-preta no Brasil. Revista Brasileira de Fruticultura, 36(1), 100-111: 10.1590/0100-2945-450/13

Bassols, M. C., \& Moore, J. N. (1981). ‘Ébano’ primeira cultivar de amoreira-preta sem espinhos lançada no Brasil: EMBRAPA UEPAE de Cascata. 16p.

Capecka, E., Mareczek, A., \& Leja, M. (2005). Antioxidant activity of fresh and dry herbs of some Lamiaceae species. Food Chemistry, 93, 223-226: 10.1016/j.foodchem.2004.09.020

Carneiro, F. M. C., Nabout, J. C., \& Bini, L. M. (2008) Trends in the scientific literature on phytoplankton. Liminology, 9: 153-158: 10.1007/s10201-008$0242-8$

Carvalho, P., Diniz-Filho, J. A. F., \& Bini, L. M. (2005) The impacto f Felsentein's "Phylogenies and the comparative method" on evolutionary biology. Scientometrics, 62: 53-66.

Chen, H. et al. (2016). Anti-inflammatory and antinociceptive properties of flavonoids from the fruits of black mulberry (Morus nigra L). PLoS ONE, 11(4), 1-14: 10.1371/journal.pone.0153080

Clark J. R. (2006). Encontro de Pequenas Frutas Nativas do Mercosul, 2.Palestras. P.11-16. (Embrapa Clima Temperado. Documentos, 171).

Lúcio, K. P., et al. (2018) Anti-Inflammatory and Antioxidant Properties of Black Mulberry (Morus nigra L.) in a Model of LPS-Induced Sepsis. Oxidative Medicine and Cellular Longevity, 1-13: 10.1155/2018/5048031

Ercisli, S., \& Orhan, E. (2007). Chemical composition of white (Morus alba), red (Morus rubra) and black (Morus nigra) mulberry fruits. Food Chem., 103(4), 1380- 1384: 10.1016/j.foodchem.2006.10.054

Gundogdu, M., Muradoglu, F., Gazioglu-Sensoy, R. I., \& Yilmaz, H. (2011). Determination of fruit chemical properties of Morus nigra L., Morus alba L. and Morus rubra L. by HPLC. Scientia Horticulture, 132, 37-41: 10.1016/j.scienta.2011.09.035

Hammer, Ø, Harper, D. A. T., \& Ryan, P. D. (2001). Past: Paleontological Statistics Software Package for Education and Data Analysis. Palaeontologia Electronica, 4(1), 1-9.

$\mathrm{Hu}$, X. et al. (2018). Isoprenylated phenolic compounds with tyrosinase inhibition from Morus nigra. Journal of Asian Natural Products Research, 20(5), 488493: $10.1080 / 10286020.2017 .1350653$

Kawvised, S., Wattanathorn, J., \& Thukham-Mee, W. (2017). Neuroprotective and Cognitive-Enhancing Effects of Microencapsulation of Mulberry Fruit Extract in Animal Model of Menopausal Women with Metabolic Syndrome. Oxidative Medicine and Cellular Longevity, 1-13: 10.1155/2017/2962316

Kawanishi, S., Hiraku, Y., Murata, M., \& Oikawa S. (2002). The role of metals in site-specific DNA damage with reference to carcinogenesis. Free Radic Biol Med, 32:822-32: 10.1016/S0891-5849(02)00779-7

Kumar, V. R., \& Chauhan, S. (2008). Mulberry: Life enhancer. Journal of Medicinal Plants Research, 2(10), $271-278$.

Kumar, A., Chauhan, P. K., Bhardwaj, V. S., Kumar, R., \& Tyagi, A. (2011). In vitro antioxidant and phytochemical investigations of ethanolic extracts of Viola serpens and Morus nigra. J. Chem. Pharm. Res, 3(4):166-71.

Laguerre, M., Lecomte, J., \& Villeneuve, P. (2007) Evaluation of the ability of antioxidants to counteract lipid oxidation: Existing methods, new trends and challenges. Review. Progress in Lipid Research, 46, 244-282: 10.1016/j.plipres.2007.05.002

Lim, S. H., \& Choi, C. I. (2019). Pharmacological properties of Morus nigra L. (Black Mulberry) as a promising nutraceutical resource. Nutrients, 11(2), 118. $10.3390 /$ nu 11020437

Lorenzi, H., Bacher, L., \& Lacerda, M. S. S. (2006). Frutas brasileiras e exóticas cultivadas (de consumo in natura). Instituto Plantarum.

Miljkovick, V., et al. (2015). Morus species through centuries in pharmacy and as food. Savremenetehnologije, 3(2), 111-115.

Morgan R. (1982). Enciclopédia das ervas e Plantas Medicinais: Hemus editora. 555 p.

Nabout, J. C., et al. (2012). Trends and biases in global climate change literature. Natureza \& Conservação, 10: 45-51. 10.4322/natcon.2012.008

Oliveira, T. N. F. L., et al. (20189). Morus nigra L.: revisão sistematizada das propriedades botânicas, fitoquímicas e farmacológicas. Archives of Health Investigation, 7(10), 450-454. 10.21270/archi.v7i10.3023

Özgen, M., Serçe, S., \& Kaya, C. (2009). Phytochemical and antioxidant properties of anthocyanin-rich Morus nigra and Morus rubra fruits. Sci. Hortic., 119(3), 275-279. 10.1016/j.scienta.2008.08.007 
Research, Society and Development, v. 10, n. 2, e49310212838, 2021

(CC BY 4.0) | ISSN 2525-3409 | DOI: http://dx.doi.org/10.33448/rsd-v10i2.12838

Padilha, M. M., Vilela, F. C., da Silva, M. J., Santos, M. H., Alves-da-Silva, G., \& Giusti-Paiva, A. (2009). Antinociceptive effect of the extract of Morus nigra leaves in mice. J. Med. Food, 12(6):1381-85. 10.1089/jmf.2009.0012

Park, E., Lee, S. M., Lee, J. E., \& Kim, J. H. (2013). Anti-inflammatory activity of mulberry leaf extract through inhibition of NF-kB. Journal of Functional Foods, 5, 178- 186. 10.1016/j.jff.2012.10.002

Pereira, A. S. et al. (2018). Metodologia de pesquisa científica. UFSM. https://repositorio.ufsm.br/bitstream/handle/1/15824/Lic_Computacao_MetodologiaPesquisa-Cientifica.pdf?sequence $=1$.

Podsekek, A. (2007). Natural antioxidants and antioxidant capacity of Brassica vegetables: A review. LWT-Food Sci. Technol, 40, 1-11. 10.1016/j.1wt.2005.07.023

Ribeiro, A. E. A. S., et al. (2019). Inhibitory effects of Morus nigra L. (Moraceae) against local paw edema and mechanical hypernociception induced by Bothrops jararacussu snake venom in mice. Biomedicine and Pharmacotherapy, 111, 1046-1056. 10.1016/j.biopha.2019.01.011

Tutin, et al. (1996).Morus L. In Flora Europa. Psilotaceae to Platanaceae. Cambrigde University Press.

Volpato, G. T., Calderon, I. M. P., Sinzato, S., Camposa, K. E., Rudge, M. V. C., \& Damasceno, D. C. (2011). Effect of Morus nigra aqueous extract treatment on the maternal-fetal outcome,oxidative stress status and lipid profile of streptozotocin-induced diabetic rats. Journal of Ethnopharmacology 138, 691-696. 10.1016/j.jep.2011.09.044

Wu, C. H., Chen, S. C., Ou, T. T., Chyau, C. C., Chang, Y. C., \& Wang, C. J. (2013). Mulberry leaf polyphenol extracts reduced hepatic lipid accumulation involving regulation of adenosine monophosphate activated protein kinase and lipogenic enzymes. Journal of Functional Foods, 5, 1620-1632. 10.1016/j.jff.2013.07.004. 